\title{
The Urgency of Law Establishment Regarding Block-Chain Technology in Indonesia Based on the Perspective of Dignified Justice (Keadilan Bermartabat)
}

\author{
Teguh Prasetyo, Rizky P.P. Karo Karo, Vena Pricilia and Natasha Setiadinata \\ Faculty of Law, Universitas Pelita Harapan, Indonesia \\ E-mail : rizky.karokaro@uph.edu
}

How to cite : Teguh Prasrtyo, Rizky P.P Karo Karo, Vena Pricilia and Natasha Setiadinata. "The Urgency of
Law Establisment Regarding Block-Chain Technology in Indonesia Based on the Perspective of
Dignified Justice (Keadilan Bermartabat)". UNIFIKASI : Jurnal Ilmu Hukum. 6(2). 2019. 177-198.
$\begin{array}{llr}\text { DOI : 10.25134/unifikasi.v6i2.1827 } & \text { Accepted : 15-11-2019 } \\ \text { Submitted : } 17-06-2019 & \text { Revised : 07-11-2019 } & \text { Act }\end{array}$

Abstract: Block-chain technology has been utilized in various countries in the world, specifically in Indonesia. Block-chain brings positive impact on the development of businesses in Indonesia, but it also has negative impacts if the government of Indonesia doesn't keep an eye on it. The Positive impacts are that block-chain can improve the efficiency of time and transactions fee. But on the other hand, block-chain gives opportunity to the beginning of cybercrime, for example data theft, client's financial data. The purpose of this research is to analyze the consumer and founder protection related on the usage of block-chain and to give an input to the ministry on the urgency of the formation of the law on blockchain in Indonesia. This research method is a normative empirical method conducted the way of analyzing norms, the laws and regulation on regarding the topic and with profound interviews with experts/officials who has decent knowledge in this specific area. The results of this study are that the blockchain technology has been used in various businesses, such as financial / banking sector, agriculture, etc. Blockchain technology can change the paradigm in the financial sector from a centralized system to a decentralized system and to improve system security. Blockchain must be monitored because the blockchain system contained data privacy, financial privacy to prevent the criminal acts. The conclusion is that the supervision of the blockchain system is carried out by forming special regulations on the blockchain or adding new norms which are based on the dignified justice about blockchain in Bank Indonesia Regulations or Financial Services Authority Regulations related to financial technology.

Keywords: Blockchain, Consumers Protection, Money Laundering, Renewal Law, Justice Dignity

\section{Urgensi Pembentukan Peraturan Perundang-Undangan terkait Teknologi Blockchain di Indonesia Berdasarkan Keadilan Bermartabat}

\begin{abstract}
Abstrak: Teknologi blockchain telah banyak dimanfaatkan di berbagai negara di dunia, khususnya di Indonesia. Penggunaan blockchain membawa dampak positif bagi pengembangan dunia bisnis di Indonesia, namun juga memiliki dampak negatif jika tidak diawasi oleh baik oleh Pemerintah Indonesia. Dampak positif penggunaan blockchain dapat meningkatkan efisiensi waktu, biaya lalu lintas transaksi keuangan. Namun disatu sisi, blockchain menimbulkan dampak negatif yakni membuka peluang munculnya kejahatan dunia maya (cybercrime) misalnya pencurian data privasi, data keuangan nasabah. Tujuan penelitian untuk menganalisis perlindungan konsumen dan pelaku usaha terkait penggunaan blockchain dan untuk memberi masukan bagi Kementerian terkait tentang urgensi pembentukan peraturan penggunaan blockchain di Indonesia. Metode yang digunakan dalam penelitian ini adalah yuridis normative. Hasil penelitian ini adalah teknologi blockchain telah dipergunakan di pelbagai usaha, baik di sektor keuangan/perbankan, pertanian dan lain sebagainya. Teknologi blockchain dapat merubah paradigma di sektor keuangan dari sistem sentralisasi menuju sistem desentralisasi dan untuk meningkatkan keamanan sistem. Blockchain wajib diawasi karena di dalam sistem blockchain terdapat privasi data, privasi keuangan dan agar tidak disalahgunakan untuk melakukan tindak pidana. Kesimpulannya adalah pengawasan sistem blockchain dilaksanakan dengan membentuk peraturan khusus tentang blockchain atau menambahkan norma baru yang berprinsipkan keadilan bermartabat tentang blockchain dalam Peraturan Bank Indonesia ataupun Peraturan Otoritas Jasa Keuangan yang terkait teknologi finansial.
\end{abstract}

Kata Kunci: Blockchain, Perlindungan Konsumen, Pencucian Uang, Pembaharuan Hukum, Keadilan 


\section{INTRODUCTION}

The development of technology in the world, especially in Indonesia has been increasing very fast. Nowadays it is known as the industrial revolution 4.0 and Japan has even reached the industrial revolution Era/Society 5.0. An example of the implementation of Society 5.0 in Japan is package shipping with a crewless drone ${ }^{1}$. The Government of Indonesia has anticipated the change since a while, in order to protect its citizens and people who uses technology to support their daily needs from other countries, the Government of Indonesia has formed "Law No. 11 of 2008 regarding Information and Electronic Transaction as amended in Law No. 19 of 2016". Humans have increasingly become more dependant towards technology, including smartphones, laptops and the internet. Such dependency has been due to the need to improve the quality of life by incorporating accessible technology and information within all sectors of life, such as government administration, business, banking ${ }^{2}$. One form of rapid technological development is the involvement of block-chain technology systems and the usage of bitcoin as the virtual currency whose value reaches 73 Million Rupiah (data taken the first week of April 2019). Block-chain was created by Satoshi Nakamoto in 2008 and it keeps developing up to now ${ }^{3}$. Frankly speaking, block-chain is a simple data structure that cannot be modified, it can only be added. Every single data inside a block-chain is connected. So if there is a change in one data block, it will effect the next data ${ }^{4}$. While the Bitcoin is a virtual currency contained in an open source network and is used as a means of payment for users of the bitcoin. Bitcoin is an example of a virtual currency that is created and maintained by using cryptographic algorithms so often called crypto currency. In addition the bitcoin there are a few types of this specific currency such as, Ripple, Litecoin, Peercoin, NXT and Dogecoin. Bitcoin was formerly created by Satoshi Nakamoto back then in 2009. According to the Bitcoin Foundation, bitcoin involve peer to peer technology so that it does not require the existence of a centralized authority or bank. Management of transaction or issuance of the bitcoin is done jointly by the network. Bitcoin is both Open Source and has a design that is open and no one is in control of the bitcoin $^{5}$. Bitcoin transactions are done anonymously or without disclosing the identity of the perpetrators at all so we don't have to bother to submit many kinds of information usually requested by bank such as source of funding, the purpose of the transaction and the address of the receiver. Due to the absence of authority that oversees bitcoin then there can be no freezing of funds, questions regarding the origin of the fund itself, and for which the transaction was conducted ${ }^{6}$. According to Kevin Werbach, "The blockchain is not just immutable; it is "censorship resistant." No higher authority can command a blockchain to do something any more than it can order around the Internet. There is no there to regulate. Regulation and the blockchain are antithetical"7. The Governor of Bank Indonesia, Agus DW (term 2013-2018) as quoted by Kompas.com stated that virtual currency has no underlying or guarantees and potentially will be the source of instability in the financial system.

\footnotetext{
1 Neneng Zubaidah, dkk, "RI Sibuk Kejar Industri 4.0, Jepang Memasuki Era Society 5.0, diaskes dari https://ekbis.sindonews.com/read/1376985/34/ri-sibuk-kejar-industri-40-jepang-masuki-era-society-50-1549586880 accesed date, 9 February 2019

${ }^{2}$ Karo, R. K., \& Sebastian, A. (2019). Juridical Analysis on the Criminal Act of Online Shop Fraud in Indonesia. Lentera Hukum, 6(1), 1-14.

${ }_{3}^{3}$ Anggoro S, "Menyoal Edukasi Blockchain dan Fintech di Indonesia", accessed from https://inet.detik.com/business/d4181870/menyoal-edukasi-blockchain-dan-fintech-di-indonesia , accesed date, 3 January 2019

4 Rachmatunnisa, "Tak Hanya Bitcoin, Blockchain Juga Potensial untuk Pertanian", accessed from https://inet.detik.com/cyberlife/d-4141401/tak-hanya-bitcoin-blockchain-juga-potensial-untuk-

pertanian?_ga=2.60567146.678540271.1555773196-286974590.1555773196 accesed date, 10 January 2019

5 Khamami H. "Bitcoin Peluang atau Ancaman?" accessed from https://bppk.kemenkeu.go.id/id/publikasi/artikel/419. artikel-teknologi-informasi/20274-bitcoin-peluang-atau-ancaman accesed date, 4 January 2019

${ }^{6}$ Ibid.

${ }^{7}$ Kevin Werbach, “Trust, But Verify: Why the Blockchain Needs the Law”, Berkeley Technology Law Journal, Vol. 33 : 487, 2018, p.522.
} 
Cryptocurrency can be used for money laundering ${ }^{8}$. Based on law No. 8 Year 2010 concerning Prevention and Eradication Of the Crime of Money Laundering (TPPU Law) was formed "because it is not only can threaten the stability of the economy and the integrity of the financial system, but also can harm the joints the life of the community, nation, and State based on Pancasila and the Constitution of the Republic of Indonesia Year 1945".

Indonesia has a "Reporting Centre and Financial Transaction Analysis (PPATK/Pusat Pelaporan dan Analisis Transaksi Keuangan"), PPATK is an independent institute which is formed in order to prevent and eradicate money laundering ${ }^{9}$. One of the PPATK's authority as stated in section 44 subsection (1) letter $\mathrm{f}$ of TPPU Law is the ACT of BEING able to recommend to law enforcement agencies on the importance of tapping or interception of electronic information and/or electronic documents in accordance with the provisions of the legislation. However, the critical question is whether the block-chain system can be intercepted? Who can intercept the system? Block-chain technology is not only about bitcoins. In this writing, author will only focus on the system of blockchain technology and the urgency of law establishment regarding this system. According to Oscar Darmawan, CEO of Bitcoin.co.id and Blockchain.co.id, stated that the establishment of block-chain is to answer the concerns on the easily hacked centralized software ${ }^{10}$. Therefore, author constitute a title of "The urgency of law establishment regarding block-chain technology in Indonesia based on the perspective of dignified justice" in order to criticize and give an advice to the authorized party on consumer and business founder protection in the utilization of block-chain technology. Based on the background as written above, then the author raised the problem formulation as follows: What is the urgency of the establishment of law concerning block-chain technology utilization in Indonesia based on the perspective of dignified justice? What kind of legal protection should be established concerning consumer and business founder protection on the utilization block-chain technology?

\section{RESEARCH METHODS}

The method used in this research is the normative empirical method. This research will be done using the normative empirical research system. Normative studies is a process of finding one principle or doctrine to address and resolve the issues at hand ${ }^{11}$. While empirical legal research is research to examine the law which conceptualized as an actual behavior as a symptom of social nature that is not written, which are experienced by everyone in the relationship in communities ${ }^{12}$. Writers conduct interviews to the Experts:

1. Pinuji Prasetyaningtyas, S.S,M.Si as a Digital Forensic Kasubdit, Directorate of Information Control, Digital Forensics, Investigation of the State Cyber and Code Agency (BSSN/ Pengendalian Informasi, Investigasi dan Forensik Digital Badan Siber dan Sandi Negara) located in Jl. Harsono RM 70, Ragunan, Jakarta Selatan

2. Prof. Dr. Sulistiowati, S.H., M. Hum as Professor of Commercial Law in the Faculty of Law in University of Gadjah Mada (UGM FH) located on Jl. Sosio Yustisia No. 1

3. Mrs. Suci, official at the Department of Law of Bank Indonesia, located in Jl. M.H. Thamrin No.2, Jakarta.

\footnotetext{
8 Sakina R, "BI Sebut Bakal Kaji Pemanfaatan Teknologi Blockchain", https://ekonomi.kompas.com/read/2018/02/02/160910326/bi-sebut-bakal-kaji-pemanfaatan-teknologi-blockchain accesed date, 3 February 2019

${ }_{10}^{9}$ Article 1 Angka 2 Law no.8 year 2010

${ }_{10}$ Oscar Darmawan, "Teknologi Blockchain , Teknologi Masa Depan" accessed from https://ekonomi.kompas.com/read/2017/10/10/120000126/teknologi-blockchain-teknologi-masa-depan accesed date, 5 February 2019

${ }^{11}$ Marzuki, P.M., Penelitian Hukum, Kencana, (Bandung: Kencana, 2005). p.35

${ }^{12}$ Abdulkadir Muhammad, 2004, Hukum dan Penelitian Hukum, (Bandung: PT Citra Aditya Bakti, 2004), p.52.
} 
4. Mr. Anton Dewantoro, as businessmen of Blockchain in Indonesia, doing Business Development for the address of Sandton Consulting, located in branch office in Ruko Bukit Cimanggu, Bogor.

5. Mr. Deivito Dunggio (Mas Oham) as The Executive Director of Asosiasi Blockchain Indonesia, located in Satrio Tower Lv.16, J1. Prof. Dr. Satrio C4, Jakarta.

The authors also use secondary data in the form of primary law materials consisting of regulations on banking-related electronic information and transaction, and other regulations related to the topic of the author. The analysis of the data used in this research is descriptive qualitative, i.e. the processing of data obtained through interviews, documentation, and libraries so that the retrieved information in the form of speech and writing to then be able to depicted in words or sentences ${ }^{13}$. Data analysis aims to simplify the processed results of qualitative data compiled by systematics in detail as follows ${ }^{14}$ : Reduction of data covering the selection, consentration, and also the transformation of raw data in the field as well as interview results. Data used will be presented to the next stage i.e. presented in table form, chart, and narrative sentences. The author will make an effort to find meaning and conclusion of existing problems, patterns of explanation, and causal flow.

\section{RESULTS AND DISCUSSION}

\section{The Urgency Of Law Establishment Regarding Block-Chain Technology In Indonesia Based On The Perspective Of Dignified Justice}

\section{The Principle Of Dignified Justice (Keadilan Bermartabat)}

"Dignified Justice is unlike the well known concept of justice, then it's worth a brief description about the Dignified Justice briefly as follows". "Dignified Justice is a Grand Legal Theory. As a new legal Theory, Dignified Justice serves to explain and give justification a system of law, which is different with Western theories that had referred to before". "A theory of Dignified Justice explains and gives justification a system of law with postulates among others that the law exist and grow in the nation's psyche or Volksgeist". ${ }^{15}$ The meaning of the phrase "the spirit of the people" or (Volksgeist) is manifested concretely and apparently shows itself empirically in two forms. The first form of the manifestation of the Indonesian spirit of law is through all of the existing legislations. The second form of the manifestation of the Indonesian spirit of law is through judemade-laws, i.e. all the final and binding court decisions, are issued by the Courts of Law in the Indonesian nation state jurisdiction ${ }^{16}$.

"The theory of Dignified Justice is not against theories that exist and are referred to in explaining the law in Indonesia". "But Dignified Justice is trying to give example on "how to rule", including building or doing construction or reconstruction on the law as well as an explanation of the law of philosophy or philosophical excavated from within the law of Indonesia itself; not always to be dependent on the theories, concepts, developed in other legal systems ". In the perspective of the Theory of Dignified Justice, or Dignified Justice, "justice is where the three legal purposes expressed by Gustav Radbruch (fairness, certainty and benefit)" assemble ${ }^{17}$. A theory of Dignified Justice drove the process of thinking as characterized as fundamentally thinking. The process of observation or thought in Dignified of Justice, as science and the theory of Justice that resulted have preferred a dignified way, roads or a scientific approach ${ }^{18}$.

\footnotetext{
${ }^{13}$ Azwar, S., 2004, Metode Penelitian, (Yogyakarta: Pustaka Pelajar, 2004). p.7

${ }^{14}$ Molcong, 2006, Metodologi Penelitian Kualitatif, Rosda Karya, Bandung. p.28

${ }^{15}$ Teguh Prasetyo, "Kejahatan Pertambangan Dalam Perspektif Keadilan Bermartabat", Jurnal PERSPEKTIF Vol XXI No. 1 Tahun 2016 Edisi January, Nomor ISSN Cetak 1410- 3648 dan ISSN Online 2406-7385, p.12.

${ }^{16}$ Teguh Prasetyo, "Pancasila The Ultimate of All the Sources of Laws (A Diginifed Justice Perspective)", Journal of Law, Policy and Globalization, Vol.54, 2016.

${ }^{17}$ Teguh Prasetyo, Keadilan Bermartabat Perspektif Teori Hukum, (Bandung: Nusa Media, 2015), p,112-113.

${ }^{18}$ Ibid, p.19.
} 
According to the author, the Government must rests upon the principle of Dignified Justice if they wish to establish a rule of law related block-chain who would later accommodate businessmen's interests, the interests of consumers, protecting personal data and also consumer's money. From the perspective of the Dignified Justice Theory, the legal limit in searching the source of laws has been established and the lawyers are to be directed to look only at the legislations and judge made laws existing in the Indonesian jurisdiction ${ }^{19}$.

\section{Renewal of Laws}

"Law No. 12 Year 2011 regarding Formation of Legislation junto. Law No. 15 Year 2019" (Law 15/2019) is an umbrella law for the competent authority to make a regulation. According Teguh Prasetyo, a good regulation is a regulation that has a clarity of purpose, clarity of the language, and it is not contrary to other regulation in creating the meaning of harmony and is applicable to all society. Under law 12/2011, the material of legislation must reflect the principles as follows: "a. the protection; b. humanity; c. nationality; d. family values; e. values of Nusantara; f. Bhinneka Tunggal Ika; g. Justice; h. equality before the law and government; i. order and legal certainty; and/or j. balance, harmony, and alignment". Under article 7 paragraph (1) of the Law 15/2019, the type and the hierarchy of legislation consists of the following, the author described it in the form of a pyramid.

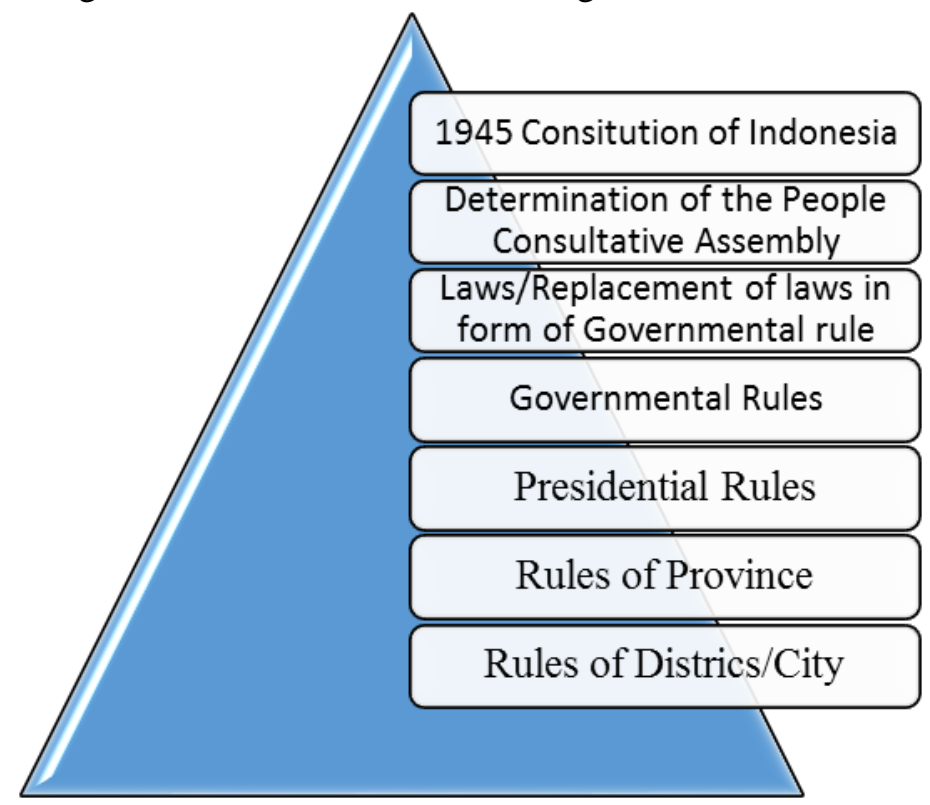

Chart 1: Illustrations from the authors about the hierarchy of legislation

In addition to the hierarchy in article 7 paragraph (1) of Law 15/2019, there are the rules established by the competent authority and the recognized regulation that is binding. The mandate set forth in article 8 paragraph (1) and paragraph (2) of the Law, article 8 paragraph (2) of Law 15/2019 are the following: "type of Legislation other than as referred to in article 7 paragraph (1) covers the rules set by the People Consultative Assembly, the House of Representatives, the Regional Representative Council, Supreme Court, Constitutional Court, the Judicial Commission, Financial Examiners, Bank Indonesia, Ministers, body, agency, or Commission level established by law or The Government at the behest of the Act, the House of representatives, Governor of the Provinces, Representatives of regional district/city, Bupati/Walikota, head of a village or a notch. "

Article 8 paragraph (2) of the Law 15/2019 "Legislation as referred to in paragraph (1) recognized its existence and had force of law that binds to all instructed by higher Legislation or

\footnotetext{
${ }^{19}$ Teguh Prasetyo, Op.Cit. “Pancasila.......”, p.107.
} 
established based on authority. " According to Teguh Prasetyo, the establishment of a law will take a very long time, done in Prolegnas (National Legislative Program) therefore laws related to blockchain technology utilization are regulated in the Ministerial Regulation, Regulation of the authorized Authority, such as the regulation of the Financial Services Authority (OJK), Bank Indonesia Regulations if the utilization of block-chain technology will then affect the stability of the payment system and the stability of the financial system. However, the weakness of the regulation is that it cannot load criminal provisions. Under article 15 paragraph (1) of the Law 15/2019 it is stated that the material provisions concerning the criminal charge can only be loaded in: a. law; b. applicable local province laws; or; c. applicable local district/city rules. According to the author, the renewal of law especially the formation of a specific law concerning block-chain is a manifestation of a futuristic interpretation conducted by the Government, specifically the legislative body. According to the author, the formation of the regulation will also form the renewal of criminal law in Indonesia. Renewal of criminal law is an attempt do the reorientation and reform of the criminal law that correspond to the value of socio-politics, socio-philosophy, and socio-cultural of the citizens of Indonesia ${ }^{20}$.

\section{The Rights And Obligations of The Providers of Electronic System}

Government Regulation No. 71 Year 2019 about System and Electronic Trascation Provider (PP 71/2019) is the legal basis of a business actors both private or Government to hold electronic system and transaction. As for the definition of the organizers of electronic systems (PSE/Penyelenggara Sistem Elektronik) according to article 1 (6a) ITE Law is "everyone, organizers of the State, community, and business entities that provide, manage and/or operate electronic systems, both individually or together to the user electronic systems for the purposes of self and/or needs of others. "Whereas definition the utilization of electronic systems is "utilization of an electronic system by the organizers of the State, people, business entities, and/or the community." PP 71/2019 firmly set the mandatory obligation of PSE that needs to guarantee:

a. The availability service level agreements ${ }^{21}$;

b. Availability of secure information agreement on the information technology services used ${ }^{22}$; and

c. Information security and means of internal communication is organized ${ }^{23}$

d. Compulsory to apply risk management against damage or loss ${ }^{24}$

e. "Ensure that the acquisition, deployment, and utilization of Personal Data based on the consent of the Personal Data owner, unless it is regulated otherwise by the laws and regulations"; and ${ }^{25}$

f. "Ensure the use or disclosure of the data is done based on the consent of the Personal Data owner and in accordance with the purposes for which it was delivered to the Personal data owner on data acquisition time" 26 .

Orders against these obligations are also regulated in POJK No.13 the year 2018:

a. The organizer is obligated to carry out the principle of self-monitoring (self-assessment) against: a. principles of corporate governance of information and communication technologies in accordance with regulation of legislation; $b$. consumer protection in accordance with the rules of

\footnotetext{
${ }^{20}$ Teguh Prasetyo, Pembaharuan Hukum: Perspektif Teori Keadilan Bermartabat (Malang: Setara Press, 2017), p.32-33.

${ }^{21}$ Article 11 paragraph (1) alphabet a Government Regulation No. 71 Year 2019

${ }^{22}$ Article 11 paragraph (1) alphabet b Government Regulation No. 71 Year 2019

${ }^{23}$ Article 11 paragraph (1) alphabet c Government Regulation No. 71 Year 2019

${ }^{24}$ Article 12 Government Regulation No. 71 Year 2019

${ }^{25}$ Article 14 paragraph (1) alphabet a Government Regulation No. 71 Year 2019

${ }^{26}$ Article 15 paragraph (1) alphabet d Government Regulation No. 71 Year 2019
} 
the financial services authority; c. education and socialization to consumers; d. confidentiality of data and/or consumers information including data and/or transaction information; e. principles of risk management and prudence; f. the principle anti-money laundering and terrorism funding prevention in accordance with the provisions of the legislation; and g. inclusive and the principle of information transparency. The monitoring and evaluation are reported periodically to OJK.

b. The organizers formed the Association of organizers in order to have a consistent operational standards \& to monitor the financial risk.

c. The organizer is obligated to draw up policies, procedures for the following aspects: a. the business strategy; b. consumer protection; c. risks and capital; d. human resources development; e. development and product planning and services; f. information technology operations; g. communication network; h. security of information; i. disaster recovery plan; j. user services; $k$. utilization of information technology service provider;

d. The organizer is obligated to put a data center and disaster recovery center in the region of Indonesia.

According to the Author, the right of business actors is provided in Law No. 8 of 1999 on Consumers Protection (Law 8/1999). That business founder have the right to:

a. "the right to receive payment in accordance with the agreement on the conditions and the exchange rate of the goods and/or services traded";

b. "right of legal protection from the consumers with no good will";

c. the right of self-defense in the judicial settlement of consumer disputes;

d. the right to rehabilitation of honor when it is legally proved that the consumers loss was not caused by the goods and/or services listed;

e. the rights set forth in other provisions or legislation.

\section{Advantages And Disadvantages Of The Utilization Of Block-Chain Technology Systems}

According to an interview result with Anton Dewantoro, Business Development for Sandton Consulting, the difference between doing a transaction with block-chain and traditional transaction is if you send e-mail so it can still be passed on to anyone even without any markers, and could anyone copy the owner, but if you use the block-chain system then it is like buying fried snacks for Rp. 10,000 then only the buyer and seller knows. Block-chain system mechanism is similar to financial ledger/ledger book entry in Banks, the notes are spread to many points and locked with encryption and if you want hacked then it is compulsory upon agreement $50 \%+1^{27}$. According to the authors, the utilization of information technology and electronic transactions has a purpose of simplifying human's task in any matter. The act of UU ITE has a mandate that technological transaction is implemented with purpose to improve the life of the nation in the matter of information; $b$. Developing the national economy in order to improve the welfare of society; c. increase effectiveness and public service efficiency; $d$. Provide a massive opportunity to every humanbeing to advance their way of thinking and their ability in the utilization of information technology as efficient as possible and responsibly e. provides safe, justice, and legal certainty for both users and actors of the information technology.

One of the technologies that are widely used nowadays is block-chain technology. According to Oscar Darmawan, a member of the member of the Indonesia FinTech Association, block-chain system shift the centralistic approach into decentralized approach. In principle, the block-chain technology customizes each server that is running software to form a network consensus that can

\footnotetext{
${ }^{27}$ Interview with Anton Dewantoro, Business Development for Sandton Consulting, March 23, 2019 at the Faculty of Law UGM, Jogjakarta.
} 
automatically replicate transaction data and to verify each data available. Therefore, when one server was hacked, this specific server can be ignored because it is considered to have different data with the majority of the other server network. This block-chain technology is relatively much stronger in facing attacks compared to centralized technology because there is always at least 1 server running to handle the transaction. Block-chain technology allows the network to record the consensus and validate each transaction so that the data entered cannot be forged, lost or damaged so as not to be manipulated by the network provider ${ }^{28}$. According to the author, the analogy of how block-chain works is similar to cash book in banks that records all transactions made by users. What distinct block-chain from cash books is that only the authorities can access information in the bank cash book, while block-chain transactions are transparent to all users because the information collected was also distributed to all the people who run the server. In addition, because the server access is given to all people, then there is no party that can falsify or modify transaction.

According to Satriyo Wibowo, a block-chain researcher, Block-chain is only one model of data base systems. Data base technology is a data storage technique either with a centralized or decentralized basis. DLT (Distributed Ledger Technology) is a distributed database technology which has a data structure resembling numbered pages arranged in a book form where when a new page is filled, the previous page cannot be changed anymore. Blockchain as part of the DLT had characterized the additional password (Cryptography) that locks a block and the previous block with in a peer-to-peer network as well as a model of consensus that determines whether a transaction block (or the pages of the book on the analogy above) is valid or does not match one of the rule validation $^{29}$. If they are decentralized, they operate based on vulnerable smart contracts. Many of them add an additional element, however, by offering their own cryptocurrency coins directly to users. These token sales create a further level of risk ${ }^{30}$.

According to an interview result with Anton Dewantoro, Business Development for Sandton Consulting, stated that block-chain system could increase customers confidence, and reduce the expense of the middle man - bank transaction ratifier $^{31}$. Blockchain is superior compare to conventional technologies because it can be implemented in various types of industrial sectors, such as supply chains and financial services. Blockchain is a record which continuosly growth, called a block, with secure connection using cryptographic techniques ${ }^{32}$. Based on the author's research, block-chain technology systems have many advantages including:

a. Security against transaction data that is reasonably safe and can be used to record transaction data in many interrelated blocks, it's safe and not only functional in terms of virtual currency but also up to voting in an election ${ }^{33}$;

b. According to Oscar Darmawan, in its principle, block-chain technology customizes each software running servers to form an automatic network consensus to replicate transactions data

\footnotetext{
${ }^{28}$ Oscar Darmawan, tanpa tahun, Artikel berjudul “Teknologi Blockchain, Teknologi Masa Depan”, accessed from https://ekonomi.kompas.com/read/2017/10/10/120000126/teknologi-blockchain-teknologi-masa-depan?page=all accesed date, 3 January 2019

${ }^{29}$ Satriyo W, dan Ery P “Jangan Pakai Blockchain” accessed from https://inet.detik.com/cyberlife/d-4053073/jangan-pakaiblockchain?_ga=2.62007915.678540271.1555773196-286974590.1555773196 accesed date, 3 January 2019

${ }^{30}$ Kevin Werbach, Op.Cit. p. 158 .

${ }^{31}$ Interview with Anton Dewantoro, Business Development for Sandton Consulting, March 23, 2019 at the Faculty of Law UGM, Jogjakarta.

${ }^{32}$ Fauzan N I, Ahmad, “Teknologi Blockchain dan Peranannya dalam Era Digital”, Jurnal BJB University, Vol 4, Des 2018, p.1.

33 Sakina R, "Tak Hanya Untuk Bitcoin, Blockchain juga bisa Dimanfaatkan untuk Bisnis", accessed from https://ekonomi.kompas.com/read/2018/03/06/170800426/tak-hanya-untuk-bitcoin-blockchain-juga-bisa-dimanfaatkanuntuk-bisnis , accesed date, 4 Feburary 2019
} 
and to verify the data. Therefore, when one server is hacked, these servers can be ignored because it is considered to have different data with the majority of the other server network ${ }^{34}$.

c. Blok-chain reduced the intermediation process between the parties in the process of transaction because each transaction is final and can be tracked to the starting point ${ }^{35}$.

d. MUFG, Japan's biggest bank, "has announced plans to launch a ' hyper-scale ' blockchain payments network to be co-developed with cloud-based delivery giant Akamai for faster, cheaper payments". "The block-chain is also capable of processing those transactions at latencies of less than two seconds per transaction - the time taken to confirm and finalize a batch of transactions on the ledger" ${ }^{\prime 36}$;

e. Block-chain can improve the efficiency payment transactions and make it more transparent because it is publicly accessible, equipped with high security level, as well as being able to minimize cases of human error because all transactions are computerized and recorded automatically ${ }^{37}$;

f. According to the interview result with Anton Dewantoro, Business Development for Sandton Consulting, when used in medical sector, the malpractice can be more easily detected due to the precise detail of the medical record and presentable system ${ }^{38}$.

In addition to excellence, block-chain systems also have weaknesses such as:

a. It will be too pricy if one's company system has run well and safe ${ }^{39}$;

b. Block-chain does not eliminate the role of the third party. The third role in this regard is the party who did the first code writing, the operator, the validator. Block-chain also cannot guarantee the exact truth of the information written down but was only able to ensure validation of the author of such information ${ }^{40}$;

c. According to the interview result with Anton Dewantoro, Business Development for Sandton Consulting, we need to put more attention on the vulnerability of block-chain due to its potential to be wrongfully utilized by drug companies and pharmaceutical companies, by changing the formulas of the $\mathrm{drug}^{41}$.

According to author, a group of people or business actors who use the block-chain system then the principle of trust and transparency become very important. The principle of block-chain is similar to the ledger in financial transactions. However, if the ledger is only owned and managed by the bank, block-chain allows the parties involved or locked within the system only to view the transaction, and the recorded block-chain cannot be manipulated as any transaction records It has been stored and dispersed in many parties in the chain. Block-chain systems can be concluded as an existence of a shift from centralized banking system become decentralized banking, where every

\footnotetext{
34 Oscar Darmawan, tanpa tahun, Artikel berjudul “Teknologi Blockchain, Teknologi Masa Depan”, accessed from https://ekonomi.kompas.com/read/2017/10/10/120000126/teknologi-blockchain-teknologi-masa-depan?page=all accesed date, 3 January 2019

${ }^{35}$ Satriyo W, dan Ery P "Jangan Pakai Blockchain” accessed from https://inet.detik.com/cyberlife/d-4053073/jangan-pakaiblockchain?_ga=2.62007915.678540271.1555773196-286974590.1555773196 accesed date, 3 January 2019

36 Samburaj https://www.ccn.com/1-million-transactions-sec-japans-largest-bank-plans-blockchain-payments-in-2020 accesed date, 5 February 2019

${ }^{37}$ Redaksi "Blockchain, Sebuah Keniscayaan? Jurnal probank, 1 No.127 Tahun XXXIV Maret-April 2017, p.1.

${ }^{38}$ Interview with Anton Dewantoro, Business Development for Sandton Consulting, March 23, 2019 at the Faculty of Law UGM, Jogjakarta.

${ }^{39}$ Satriyo W, dan Ery P “Jangan Pakai Blockchain” accessed from https://inet.detik.com/cyberlife/d-4053073/jangan-pakaiblockchain?_ga=2.62007915.678540271.1555773196-286974590.1555773196 accesed date, 3 January 2019

${ }^{40}$ Satriyo W, dan Ery P “Jangan Pakai Blockchain” accessed from https://inet.detik.com/cyberlife/d-4053073/jangan-pakaiblockchain?.ga=2.62007915.678540271.1555773196-286974590.1555773196 accesed date, 3 January 2019

${ }^{41}$ Interview with Anton Dewantoro, Business Development for Sandton Consulting, March 23, 2019 at the Faculty of Law UGM, Jogjakarta.
} 
customer can manage their money, transfering without intermediaries, without intervention of a third party/parties of the bank.

Can block-chain be used for activities other than financial transactions? The answer is no. Block-chain technology can be used to advance the company's business more broadly. For example, the Government of Singapore use block-chain to help businesses in the port to shorten the ship's waiting period or dwell time, verify the transaction related export \& import ${ }^{42}$. The second example is SAP Information Collaboration Hub for Life Sciences use block-chain technology hub to help eliminate counterfeit products along the pharmaceutical supply chain. "The blockchain-based solution helps customers comply with the U.S. Drug Supply Chain Security Act (DSCSA), which requires that as of November 2019 wholesalers verify prescription drugs that are returned and intended for resale". The mandate is intended to protect consumers from fake, stolen and contaminated medication ${ }^{43}$. The third example is $\mathrm{X}$ that is a company that focuses on the use of virtual currency ${ }^{44} . X$ is collaborating with HARA, a company present in Indonesia since 2015 and based in Singapore. According to Regi Wahyu, CEO of HARA, HARA was built to realize the prosperity of the economy through a block-chain based decentralized exchange data ${ }^{45}$. As for the reason of HARA utilizing block-chain is that: 1. it Enables a decentralized and scalable ecosystem; 2. "Ensures data integrity where every source is traceable"; 3. Efficiently distributes incentives directly to stakeholders ${ }^{46}$. A similar thing is stated by Anton Dewantoro, the use of block-chain in the agricultural sector will greatly help the farmers because the search process trace, agriculture from the first day of planting, treatment/engineering process noted in block-chain, the data are then disseminated to users of blok-chain so that the transparency of the process is fast ${ }^{47}$.

The fourth example is the use of block-chain by Indonesia Creative Economy Body (BEKRAF) in the field of music industry ecosystem in Indonesia. According to Triawan Munaf, head of the BEKRAF (Period 2015-2019) that "the Block-chain ensure the added value of creation because it uniquely made everyone agree that a specific work was created by a particular person. This is in line with the process in the music industry, later from the publication and promotion activities will be regenerated and decentralized to provide benefits for musicians, especially financialial benefits ". ${ }^{48}$ Blockchain Technology is superior technology because blockchain can be implemented in various types of industrial sectors, such as supply chain and financial services. Blockchain allows the transaction process to run without one server but connecting between computer networks in a decentralized and distributed process.

\section{Not Only Based On The Agreement}

According to the authors, because there haven't been any regulations from the authority on the utilization of block-chain then currently the utilization of block-chain is based on agreement, and tied in a 1320 KUHPerdata article on terms of a legitimate agreement. According to the authors, if it still

\footnotetext{
42 Sakina R, "Tak Hanya Untuk Bitcoin, Blockchain juga bisa Dimanfaatkan untuk Bisnis", accessed from https://ekonomi.kompas.com/read/2018/03/06/170800426/tak-hanya-untuk-bitcoin-blockchain-juga-bisa-dimanfaatkanuntuk-bisnis , accesed date, 4 Feburary 2019

43 SAP News Center "New Blokchcian Software from SAP Helps Eliminate Counterfeit Drugs", accessed from https://news.sap.com/2019/01/sap-information-collaboration-hub-life-sciences-blockchain-eliminate-counterfeit-drugs/ , accesed date, 20 January 2019

${ }_{44}^{44} \mathrm{https} / / /$ pundix.com/about accesed date, 21 January 2019

45 Marsya, HARA Ingin Bantu Atasi Isu Perekonomian Lewat Pertukaran Data Berbasis Blokchain accessed from https://dailysocial.id/post/hara-blockchain accesed date, 21 January 2019

${ }^{46} \mathrm{https}$ ://haratoken.io/\#home accesed date, 21 January 2019

${ }^{47}$ Interview with Anton Dewantoro, Business Development for Sandton Consulting, March 23, 2019 at the Faculty of Law UGM, Jogjakarta.

${ }^{48}$ M. Imron, "Blockchain Bakal Diterapkan di Industri Musik Indonesia" accessed from https://inet.detik.com/cyberlife/d4048122/blockchain-bakal-diterapkan-di-industri-musik-indonesia? ga=2.62007915.678540271.1555773196$\underline{286974590.1555773196}$ accesed date, 5 February 2019
} 
requires an agreement, then it must be agreed by parties, stakeholders, the third party regarding the data can be replaced? Who can access and read the data? Security on the data so that it is not distributed carelessly.

\section{Another Country's Policy Against Blockchain}

Authors had described above that bitcoin is just one of the virtual currency products running through a block-chain system. In Indonesia, one of the famous website who received bitcoin as its media of exchange is Codashop that is a place to buy game credits such as Steam and Google Play Gift. In other countries, Bitcoin can only be used or exchanged in websites with money conversing features that can switch bitcoins into real money that can be used for the owner's needs.

Authors will describe in a form of table the countries that has a policy on block-chain and block-chain products (virtual currency) as follows:

\begin{tabular}{|c|c|c|}
\hline COUNTRY & BLOCKCHAIN & CRYPTOCURRENCY (BITCOIN) \\
\hline $\begin{array}{l}\text { UNITED } \\
\text { STATES } \\
\text { OF } \\
\text { AMERICA }\end{array}$ & $\begin{array}{l}\text { The United States government has } \\
\text { expanded the utilization of block-chain } \\
\text { technology in various government } \\
\text { systems and also in private sector. The } \\
\text { U. S. government is seriously } \\
\text { suggesting the potential of block-chain } \\
\text { technology and supporting to adopt the } \\
\text { technology in various fields, } \\
\text { specifically to rode bureaucracy of } \\
\text { consumers empowerment, and } \\
\text { encourage the progress of the country's } \\
\text { economy. } \\
\text { In the Information Technology sector at } \\
\text { the Department of Health and Human } \\
\text { has issued a statement on how block- } \\
\text { chain technology could be } \\
\text { implemented in the health setting }{ }^{49} \text {. }\end{array}$ & $\begin{array}{l}\text { The United States has pro - bitcoins } \\
\text { attitudes. The United States Department } \\
\text { of Finance categorize bitcoin as Mones } \\
\text { Service Business (MSB), but not a } \\
\text { currency. This definition puts it under } \\
\text { some obligation, like reporting, } \\
\text { registrating, and keeping notes. To } \\
\text { Internal Revenue Service, bitcoin is } \\
\text { considered a property with an applied tax. } \\
\text { In some countries it refers to assets like } \\
\text { gold or artwork with a worth of money. } \\
\text { The United States of America is one of } \\
\text { the few government that has worked out } \\
\text { or minimize the use of cryptocurrency for } \\
\text { illegal purposes }{ }^{50} \text {. } \\
\text { The United States has released the } \\
\text { regulation regarding bitcoin with the } \\
\text { name BitLicense and well-known } \\
\text { companies, like Microsoft, Rakuten, } \\
\text { Overstock, and Time Inc is now receiving } \\
\text { payment through bitcoins }{ }^{51}\end{array}$ \\
\hline ESTONIA & $\begin{array}{l}\text { Estonia has tested block-chain } \\
\text { technology since } 2008 \text {. Estonia is } \\
\text { called the pioneer country of block- } \\
\text { chain and since } 2012 \text { block-chain had } \\
\text { been used in the registry of the estate } \\
\text { data in health, court materials, security, }\end{array}$ & $\begin{array}{l}\text { The use of bitcoin was not regulated or } \\
\text { controlled by the Estonian government } \\
\text { but the Estonian government revealed } \\
\text { that they consider the launch of its } \\
\text { country's own cryptocurrency called } \\
\text { "estcoin", which was planned would be }\end{array}$ \\
\hline
\end{tabular}

\footnotetext{
${ }^{49}$ https://blog.indodax.com/pemerintah-amerika-serikat-memperluas-penggunaan-teckhnologi-blockchain/ accesed date, 3 February 2019

${ }^{50}$ Is Bitcoin Legal?, http://www.coindesk.com/information/is-bitcoin-legal/ accesed date, 2 February 2019

51 Kurniasih Miftahul Jannah, Jepang Jadikan Bitcoin Mata Uang Perlukah di Indonesia?, http://economy.okezone.com/read/2016/05/16/20/1389411/jepang-jadikan-Bitcoin-mata-uangperlukah-diindonesia?utm_source=economy_b
} 
and commercial to implement the purpose of block-chain in cyber security $^{52}$, almost the entire Estonian public service has been digitalized and decentralized.

\section{NEW \\ ZEALAND}

\section{CANADA}

SWISS
Blockchain's efficiency and safety in keeping data been luring the government and some business across New Zealand to start experimenting with block-chain technology. Air New Zealand is examining the use of blockchain in baggage tracking, retail sales, and member loyalty program to the airline $^{54}$. New Zealand has not regulated the laws on block-chain

The Canadian government is
examining the use of block-chain in public research funding and funding information done by the government to be shared live and transparant. Thus, the public can see the recent live database. Furthermore, the Canadian Government have issued the blockchain based mutual funds exchange trade (ETF/Exchange Trade Fund) in the Toronto Stock Exchange

The City of Zug in Switzerland has offered a flexible tax system as a protection for companies that has adopted block-chain technology. On July 2018 Zug has used block-chain technology in the elections, where the government issues digital identity to its citizens and conducting elections through an app ${ }^{57}$. sold to collect the money for the state's eresidence program. The e-residency program is a program that provides the residency to anyone in the world and non - Estonian can acknowledge access to Estonia's services as corporation formation, banking, payment processes, and $\operatorname{tax}^{53}$

Non - bank entities don't need approval for storing or transferring bitcoin, as long as they are not involved with money publishing ${ }^{55}$

Canada has taken a positive approach to bitcoins. Canadian Revenue Agency (CRA) considered it as a commodity (a revenue accepted due to the transaction is considered one business). Tax may vary, depending on how it works. Bitcoin is considered a buy-and-sell business or just like investments, other than that, in Canada regulations in anti-money laundering is applicable in bitcoin exchange ${ }^{56}$.

Zurich, the capital city of Swiss had first released a bitcoin ATM four years ago (2014). The City of Zug received bitcoins as payment for government services. City of Ciasso, receive bitcoins as a form of tax payment. Besides, bitcoin business in Switzerland works under the regulation of anti-money laundering and sometimes requires banking license ${ }^{58}$.

\footnotetext{
${ }^{52}$ https://e-estonia.com/wp-content/uploads/faq-a4-v02-blockchain.pdf accesed date, 3 February 2019

53 https://bitnews.co.id/estonia-akan-meluncurkan-estcoin/ accesed date, 3 February 2019

${ }_{54}$ https://www.digitalistmag.com/digital-economy/2018/04/12/5-benefits-to-adopting-blockchain-in-new-zealands-retailsector-06064415 accesed date, 3 February 2019

${ }^{55} \mathrm{https}: / /$ www.loc.gov/law/help/bitcoin-survey/\#newzealand accesed date, 3 February 2019

56 https://unichange.me/in/articles/legal_status_of_bitcoin accesed date, 3 February 2019

57 https://bitcoinmagazine.com/articles/switzerlands-crypto-valley-successfully-completes-blockchain-voting-trial/ accesed date, 3 February 2019

${ }^{58}$ https://cryptocurrencynews.com/blockchain-in-switzerland accesed date, 3 February 2019
} 
ARAB SAUDI

SINGAPORE

JAPAN
Saudi's central Arabic Bank has signed a deal with Ripple company based in the US to utilize the block-chain technology owned by Ripple to help banks within the kingdom, to complete domestic and international finance matter, which allows transactions to be faster, cheaper and more transparent. Saudi Arabia and UAE have a plan to extract the digital currency to facilitate a boundless transaction between the two 59

Through the Ubin project, Singapore Financial Authority, had partnered with R3, a block-chain technology company in running the projects of the bank experiments on the bank's payments via block-chain. According to the view of the government of Singapore, blockchain technology can provide the ability to transparent, more efficient, and cheaper financial transactions ${ }^{61}$.
The laws on the cryptocurrency are relatively mild in Singapore. Their tax authority in Singapore has entered a new tax guidelines for the virtual currency business as a revenue that is charged with normal revenue laws. The business that buys or sells digital currency's is necessary to record the value of the currency in that specific time. The business that flourished in the trade, including miner and the Bursa will be charged with tax over the profit, while long term businesses will benefit zero capital from the profit gained by trading currencies.

The business that received bitcoins in exchange for the goods and their services were legal, but with a pretty large warning that there was a great risk, and subdued to local tax regulations ${ }^{62}$.

The Japanese national parliament supports block-chain and cryptocurrency, being one of the first countries in the legitimation of ICO (Initial Coin Offering) by allowing bitcoins as a retail payment. Virtual currency in Japan is considered a form of payment and requires a currency exchange, in order to do businesses in Japan than a company

\footnotetext{
59 https://www.reuters.com/article/us-saudi-cenbank-currency/saudi-arabias-central-bank-signs-blockchain-deal-withripple-idUSKCN1FZ0LD accesed date, 3 February 2019

${ }^{60}$ Ibid.

61 https://cointelegraph.com/news/singapores-government-blockchain-experiment-is-a-road-to-regulatory-understanding accesed date, 3 February 2019

62 https://bravenewcoin.com/news/bitcoin-regulation-in-singapore-an-inside-look/accesed date, 3 February 2019
} 
up the transaction process and suppress the transaction costs ${ }^{63}$. shall obey and register to the Financial Service Agency.

Some major companies have adopted bitcoin like Denki.co, LINE (a text provider) that launched the crypto exchange and the big banks who invested millions of dollars into block-chain startups. Bitcoin is officially approved as a method of payment in 2017, but not as an official currency ${ }^{64}$.

INDONESIA Indonesia haven't regulate the The Indonesian government prohibits the utilization of block-chain system use of virtual currency as a legitimate means of payment

\section{The Relationship Between Block-Chain With Currencies In Indonesia}

The Government strongly declare that bitcoin, as a virtual currency cannot be used as means of payment. Based on Law No. 7 of 2011 on Currency (Law 7/2011) jo. Bank Indonesia regulation (PBI/Peraturan Bank Indonesia) 18/40/PBI/2016 on Conducting of Payment Transaction Process jo. PBI 19/12/PBI/2017 on Financial Technology Conducting stated that payment transactions and finance in Indonesia is obliged to use the Rupiah.

According to Ibu Suci, an official in Bank Indonesia Law Department, virtual currency (vc) is not legal tender. The VC is not recognized in any country because it is not the official currency issued by the Government authorities, one example of a vc is bitcoin. Fluctuation of bitcoin is either too sharp or too low, no measurement, comparison, or other economic ways to lower that rate. If the State banned the bitcoin then the customer would not want to keep bitcoins than the bitcoins will be sold and the price will drop. If the price goes down than the government has to authority to be responsible to it ${ }^{65}$.

\section{The Form Of Legal Protection For Consumers And Business Actor On The Utilization Of Block-Chain Technology}

\section{Protection by Bank Indonesia}

Indonesian bank has not regulated block-chain as a method of payment. According to Ibu Suci, an official at the Law Department of Bank Indonesia, Bank Indonesia has issued Indonesian Bank Regulations 18/40/PBI/2016 on Conducting of Payment Transaction Process (PBI 18/2016) and Indonesian Bank Regulation 19/12/PBI/2017 on Financial Technology Conducting (PBI $19 / 2017)^{66}$.

According to authors, PBI 19/2017 classifies block-chain as a financial technology conductor or as a category in a payment system. The payment system includes authorization, clearing, final

\footnotetext{
${ }^{63} \mathrm{http}: / /$ fortune.com/2018/05/21/bank-japan-mitsubishi-blockchain-akamai// accesed date, 3 February 2019

64 https://bitcoinmagazine.com/articles/how-japan-creating-template-cryptocurrency-regulation/_accesed date, 3 February 2019

${ }^{65}$ Interview with the Mrs. Suci Officer in the Bank Indonesia Legal Department at the UGM Faculty of Law on March 23, 2019

${ }^{66}$ Interview with the Mrs. Suci Officer in the Bank Indonesia Legal Department at the UGM Faculty of Law on March 23 , 2019
} 
settlement, and execution of payment. By referring to its function written above, block-chain doesn't need a third party as a medium, if the system is not being controlled than it could be a media of money laundering. According to the authors, Bank Indonesia must select strictly the block-chain business authors in the banking sector, specifically oversaw whether the submission of block-chain business is in accordance with the principles of belief, principles of discretion and the know your customer (KYC) principle. If it has fulfilled all four principles then the perpetrator of block-chain is eligible of business permission.

\section{Preventive Efforts by OJK}

According to the authors, consumers are in a very weak position, consumers adopting the block-chain system are helpless in the matter of loss. Based on the author's research, the application of block-chain to the present are categorized as other financial activities. Other financial activities have been regulated in the regulation of the Financial Services Authority (OJK) no. 13/POJK. 02/2018 (2018 Year RI State Gazette, no. 135, State Gazette Supplementary No. 6238) about Financial Innovation in Digital Financial Services Sectors (will now be mentioned as POJK 13/2018). Digital financial innovation can not be ignored and it has given the maximum benefit for the community. However, if the innovation is not set more in a specific way, it would give a huge risk to the consumer, the consumer has no protection. POJK 13/2018 obliged the author of Digital Finance Innovation (IKD/Inovasi Keuangan Digital) to apply basic principles of consumer protection: a. transparency, b. fair treatment c. reliability, d. confidentiality \& security of consumers data/information, e. complaint handling and dispute settlement to be done simply, fast, and with an affordable price, f. provides technology-based consumer service center ${ }^{67}$. OJK also authorized to perform certain actions ${ }^{68}$. Based on 13/2018 POJK article 1 1, Digital Financial Innovation (IKD) is an activity of the renewal of business processes, business model, and the financial instruments that provide new value added in financial services sectors by involving the digital ecosystem. OJK as an authorized State institutions on the financial services sector have the authority conducting the testing mechanisms for assessing the reliability of business processes, business models, finance \& governance instrument Organizer who organizes the IKD, the authority is known as "regulatory sandbox". Based on article 4 POJK 13/2018, OJK give criteria in doing IKD: a. are innovative and future oriented; b. use of information and communication technology as a primary means of administering services to consumers in the financial services sector; c. support the financial literacy and inclusion; d. beneficial and can be used widely; e. can be integrated in existing financial services; f. using a collaborative approach; and; g. take notice of aspects in consumer protection and data protection. This mandatory IKD criterion must fulfill the requirements of the regulatory sandbox ${ }^{69}$. As for the scope of IKD as set forth in article 3 POJK/2018 is:

a. settlement, investment related settlement;

b.gathering together the capital as equity crowdfunding, virtual exchange and smart contract, as well as alternative due diligence.

c. management of investments such as advance algorithm, cloud computing, open source-sharing capabilities, information technology, automated advice and management, social and retail trading, algorithmic trading.

d.gathering together and channeling the funds as loan borrowing-based technology applications (P2P lending), adjudication alternative, virtual technologies, mobile 3.0, and third-party application programming interface.

\footnotetext{
${ }^{67}$ Article 31 paragraph (1), (2) POJK 13/2018

${ }^{68}$ Article 40 POJK 13/2018

${ }^{69}$ Article 7 paragraph (1) POJK 13/2018
} 
e. As an insurance in form of, "sharing economy, autonomous vehicle, digital distribution, and securitization and hedge funds".

f. "market support in the form of, artificial intelligence/machine learning, machine readable news, social sentiment, big data, market information platform, and automated data collection and analysis".

g. other digital financial backer); and/or social/eco crowdfunding, Islamic financing, digital ewaaf, ezakat, robo advise and credit scoring.

h. activities of other financial services include invoice vouchers, trading, token, application-based products and block-chain.

OJK requires that organizers are financial services institution; and/or other parties that perform activities in the financial services sector. If it refers to Law 21/2011 OJK, that under article 1 (4) OJK Law, the definition of Financial Service Agency (LJK/Lembaga Jasa Keuangan) is an agency that is working on banking, capital market, insurance, pension funds, funding agency, and other financial service agency, whereas under article 1 point $10 \mathrm{UU}$ OJK, understanding of other financial services institutions are pawnshop, guarantee agency, Indonesia export funding agency, secondary housing funding agency, financing companies and institutions that managed the mandatory Community Fund, including the organizers of the program social security, pensions, and welfare, as stipulated in laws and regulations concerning pawnshop, the securing of financing institutions, Indonesia's exports, secondary housing, finance companies and fund management community that is mandatory, as well as other financial service institution declared overseen by OJK based on legislation. Based on this, a 13/2018 OJK POJK require organizer to perform three (3) a legal obligation, namely:

a. The application for registration. This obligation is excluded for the parties that have been registered or have received permission from OJK. As for the required documents is a. a copy of the organizer's legal entity deed of incorporation along with the identity of the completeness of the data administrators; b. a brief explanation in writing of the product; c. data and other information related to the activities of the IKD; and d. a business plan ${ }^{70}$;

b. Meet Regulatory Sandbox. OJK establish organizers to be tested in Regulatory Sandbox. This assignment is done against the organizer with the following requirements: a. a. IKD recorded as at the financial services authority or on the basis of the statement of claim filed in the related supervisory work unit of the financial services agency $(\mathrm{OJK})$; b. is the new business model; c. have the scale of effort with a broad market coverage; d. registered in the organizer's association ; and e. other criteria set by the financial services agency $(\mathrm{OJK})^{71}$.

A period of organizing regulatory sandbox is the one (1) year and may be extended for 6 (six) months if necessary ${ }^{72}$. During the implementation of regulatory sandbox. The Organizer is obligated to fulfill the following conditions: a. notify each IKD change owned; b. commit to open any information relating to the implementation of the Regulatory Sandbox; c. follow education and counseling necessary for business development in the financial services sector; d. follow any implementation of the coordination and cooperation with the authorities or ministries/agencies; and e. collaborate with the financial services Agency or party activities in the financial services sector.

\footnotetext{
${ }^{70}$ Article 6 paragraph (3) POJK 13/2018

${ }^{71}$ Article 8 paragraph (2) POJK 13/2018

${ }^{72}$ Article 9 POJK 13/2018
} 
The status of regulatory sandbox result will be: a. recommended; b. repair; or c. not recommended ${ }^{73}$. If recommended status is given then OJK will provide recommendations for registration in accordance with the business activities of the Organizer ${ }^{74}$. If the repair status is given, then OJK will give 6 (six) months extension from the date of the determination of status ${ }^{75}$. If the status is not recommended then the organizers cannot resubmit the same IKD and will be issued from the recording as an organizer ${ }^{76}$. 3. Registration. Application to the financial services agency (OJK) no later than 6 (six) months from the determination of the status of recommended ${ }^{77}$. If it exceeds the time period then the status revoked \& stated does not apply.

\section{Surveillance Efforts Against Block-chain System}

OJK obligatory monitoring of the entire good organizers that have not been recorded but has been operating, the organizers have been recorded \& registered in OJK. According to the author, efficient monitoring based on periodic reports organizer, direct monitoring, by the report of the community; OJK is obligated to conduct surveillance against: a. the ethical standards of the profession and the market; b. transparency of products and services; c. competitive and inclusive market; d. conformity with the needs of consumers; e. handling the complaints mechanism; f. Security and confidentiality aspects of consumer data and transactions; g. aspects of compliance with the regulations; h. standard and security aspects of the platform; i. information technology governance aspects; a. market risk; k. counter-party risk and clearing agency; b. aspects of online education; and $\mathrm{m}$. aspects of electronic certificates. According to Sulistiowati, supervision of blockchain is required by all parties, in particular, the Ministry of communications and Informatics, Bank Indonesia, the financial services agency (OJK), the State police of the Republic of Indonesia (the national police / POLRI), the center of reporting and Financial Transaction Analysis (PPATK) ${ }^{78}$. The cooperation between these institutions are urgently needed to prevent block-chain based banking cybercrime. OJK is also obliged to guard consumers who suffer consumer losses to get their money back in a civil suit ${ }^{79}$.

\section{Supervision towards the utilization of Personal Data by the Organizer of Block-chain}

Personal data in the form of electronic data is important in an increasingly modern world. According to the author's personal data-saving and wealth that is contained in the system is the block-chain stuff as categorized in Article 499 of Indonesia Civil Code, "goods are material and rights that can be an object to right of ownerships". The personal data is obliged to be maintained confidential, intact, available by the organizers of the block-chain.

Organizers can exploit block-chain data \& block-chain user information after fulfilling; a. gain approval from the user, b. convey data \& information utilization restrictions to users, c. convey any change of the purpose of utilization data \& information to users in the event of a change of the purpose of utilization data and information, d. media \& methods used in obtaining data \& information guaranteed confidentiality, security and unity. According to the author, organizers are prohibited from providing data and/or information about consumers to third parties ' unless ' If a. the consumer giving consent electronically, and/or $b$. organizer is required by the provisions of

\footnotetext{
${ }_{73}$ Article 11 paragraph (1) POJK 13/2018

${ }^{74}$ Article 11 paragraph (2) POJK 13/2018

${ }^{75}$ Article 11 paragraph (3) POJK 13/2018

${ }^{76}$ Article 11 paragraph (4) POJK 13/2018

77 Article 14 paragraph (3) POJK 13/2018

${ }^{78}$ The results of the interview with Prof. Dr. Sulistiowati, S.H., M. Hum as Professor of Commercial Law at the Faculty of Law, Gadjah Mada University (FH UGM), at the UGM Faculty of Law, March 23, 2019

${ }^{79}$ Rizky Karo Karo, Artikel “Kejahatan Siber Perbankan”, Kolom Opini Harian Kompas tanggal 27 Juli 2018.
} 
legislation to provide the data and/or information about consumers to third parties. According to Sulistiowati, the owner of the data in the block-chain system is a block-chain provider company. Therefore, the company is subject to the mandatory rules from the Minister of Informatics and Communications No. 20 Year 2016 on the Protection of Personal Data in the Electronic System (Permenkominfo 20/2016) one of which is the organizer of the electronic system the owner must respect personal data over the nature of the personal data privacy ${ }^{80}$.

Nowadays, the protection of personal data is only in the form of Permenkominfo, hence Kominfo Minister is obliged to cracked down decisively by giving administrative sanctions to perpetrators attempt either: a. an oral warning, written warning, b. c. temporary activity termination, d. announcements on a site in the network ${ }^{81}$. Blockchain developers cannot ignore the law, but neither can governments disregard the growing significance of the blockchain. One way to bridge the gap is for law to adapt. Some of that will happen naturally as regulators, legislators, and judges confront the challenges and opportunities this foundational new technology presents ${ }^{82}$. According to Mr. Deivito Dunggio (Mas Oham) as The Executive Director of The Indonesian Blockhain Associaton/Asosiasi Blockchain Indonesia, Blockchain develops fast but until now the specific regulations regarding blockchain technology have not yet established, then, blockchain is due to an agreement/contract of its users. Blockcain is a distributed ledger techonology (DLT), or decentralized data. DLT is umbrella terms rather than blockchain. Dlt has many types, but DLT has been going well for ten years is the blockchain ${ }^{83 .}$

\section{Prevention And Prosecution Of The Crime Of Money Laundering}

According to Black's Law Dict, the definition of money laundering is "money laundering is a term used to describe an investment or any other money transfer flows form of extortion, drug deals and other illegal to legal channels so the original source can not be tracked. " According to N.H.T. Siahaan, the nature of the crime of money laundering is related to background back from obtaining a sum of money which is dark, dirty or unclean, then a number of dirty money is administered by certain activities with forming a business, transfer or convert them into a bank or foreign currency in order to erase the background of the dirty money ${ }^{84}$. According to Adrian Sutedi, in general stages of money laundering:

a. Placement, Placement is the owner of money placing the money gained against the law into the financial system. The form of the money is hidden so that the origins of the money is unknown;

b. Layering (transfer), Layering is the phase where the money launder try to cut down the relationship between the filthy money and the source by moving the money into a bank and another and also by dividing the amount of money

c. Integration (using the treasures), Integration or sometimes called a spin Dry is to use the results of a money-laundering into the shape of a net income tax became as if the money is ' clean money ${ }^{.85}$

\footnotetext{
${ }^{80}$ The results of the interview with Prof. Dr. Sulistiowati, S.H., M. Hum as Professor of Commercial Law at the Faculty of Law, Gadjah Mada University (FH UGM), at the UGM Faculty of Law, March 23, 2019

${ }^{81}$ Rizky Karo Karo, Penegakan Hukum Kejahatan Dunia Maya (Cybercrime) Melalui Hukum Pidana (Karawaci: Penerbiit Fakultas Hukum UPH, 2019), p.. 155.

${ }^{82}$ Kevin Werbach, Op.Cit, p. 539.

${ }^{83}$ Interview results with Mas Oham, Executive Director of Asosiasi Blockchain Indonesia, on 16 May 2019 di Satrio Tower Lv.16, Jakarta.

${ }^{84}$ N.H.T Siahaan, Pencucian Uang Dan Kejahatan Perbankan, (Jakarta: Pustaka Sinar Harapan, 2005), p. 3

${ }^{85}$ Adrian Sutedi, Tindak Pidana Pencucian Uang, (Bandung:PT Citra Aditya Bakti, Bandung 2008), p.18-21
} 
Based on article 2 paragraph (1) of the TPPU Law, the result of a criminal act is the wealth gained from the crime:

a. corruption;

b. bribery;

c. narcotics;

d. psychotropic substances;

e. labor smuggling;

f. migrant smuggling;

g. in the field of banking;

h. in the capital market;

i. in the field of insurance;

j. Customs;

k. excise;

1. human trafficking;

m. illegal weapon trafficking;

n. terrorism;

o. kidnapping;

p. theft;

q. embezzlement;

r. fraud;

s. counterfeiting money;

t. gambling;

u. prostitution;

v. in the field of taxation;

w. in forestry;

$\mathrm{x}$. in the field of the environment;

y. in the field of marine and Fisheries; or

z. other criminal offence is liable to a criminal prison four (4) years or older, conducted in the territory of the Republic of Indonesia or done outside of the Republic of Indonesia and the crime is a crime under the Indonesian law.

According to Yunus Husein, an effort is required to cut the chain of crimes of moneylaundering: with a way to foreclose and seize proceeds of crime, in addition to the relatively easy to do but it will also be able to eliminate the motivation to commit crime again ${ }^{86}$. According to the authors, article 23 paragraph (1) of the TPPU Law finance service provider must report to the PPATK including: a. receipt of suspicious financial transaction; $b$. acceptance of financial cash in the amount of at least Rp 500 million (with five hundred million rupiah) or with foreign currencies whose value equivalent, which performed well in a single receipt or acceptance several times within 1 (one) working day; and/or c. financial acceptance of transfer of funds to and from foreign countries. Suspicious financial acceptance criteria is a. financial acceptance deviate from the profile, characteristics, or habitual patterns of acceptance from users of the service concerned; $b$. financial acceptance by users of the service are thought to do in order to avoid reporting the corresponding receipt that must be carried out by the Rapporteur trust accordance with the provisions of this Act; c. acceptance finance is done or cancel is done using treasures thought to derive from the results of a criminal offence; or d. financial receipts requested by PPATK to reported by trust the rapporteur because it involves the alleged wealth derived from the results of a criminal offence ${ }^{87}$.

\footnotetext{
${ }^{86}$ Yunus Husein, Bunga Rampai Anti Pencucian Uang, (Bandung : Terrace \& Library, 2007), p. 289

${ }^{87}$ Article 1 Angka 5 Law No. 8 Year 2010
} 
The Indonesia Government (PPATK/OJK) should coordinate globally to prevent cybercrime from using the blockchain technology. Global coordination is fundamental to ensure the realization of the benefits and the expansion of the blockchain technology, as well as to set any necessary protections for the system. the regulation needs to be flexible enough to allow for innovation. ${ }^{88}$

\section{Sanctions Against Organizers Of Block-chain}

POJK 13/2018 set of sanctions if POJK 13/2018 is breached: a. a written warning, b. fine, obligation to pay a certain amount of money, c. cancellation of approval, and/or d. cancellation of registration ${ }^{89}$. According to Sulistiowati, if Bank Indonesia had given permission, then that can revoke Bank Indonesia is permission, and the post of Bank Indonesia has provide permission then it is the form that the State is present ${ }^{90}$. However, the sanction is not tough enough, if a block-chain business actor intend to do the crime of embezzlement by weighting down as set forth in article 374 of the PENAL CODE then criminal sanctions is appropriate given ${ }^{91}$. Criminal law function set life civic and organized layout within the community ${ }^{92}$. Criminal sanctions may only be carried out if there are any additions or changes to Article in UU until today ITE Law only regulate on hacking in article 32 paragraph $(1)^{93},(2)^{94}$ and $(3)^{95}$ and if it violates Article 32 paragraph (1) of the ACT ITE then threatened with imprisonment of not longer than 8 (eight) years and/or a fine of Rp 2 billion, while if the violation of article 32 paragraph (2) of the ACT ITE then threatened with imprisonment longest 9 (nine) years and/or a fine of Rp 3 billion, while if the violation of article 32 paragraph (2) UU ITE then threatened with imprisonment of not longer than 10 (ten) years and/or a fine of Rp 5 billion.

\section{CONCLUSION}

Technology system has changed the paradigm of block-chain trade and block-chain consumer. The urgency of the establishment of the rule of law specifically governing the compulsory blockchain must be formed immediately, do not let the dispute arising from the present State through new regulations issued by the Government. The use of block-chain has been used by other countries and the very worthwhile. The utilization of blockchain is not only to payment system but can also be applied to other sector, for example in the agricultural sector whose results are used for the prosperity of farmers. Block-chain technology systems is a technology that changed centralized into decentralized data. If currently the consumers private data can only be accessed by the company but with block-chain all the related parties inside the boock-chain may access the data.

The form of the legal protection of consumers and businessmen towards the utilization of the technology of block-chain is poured in the form of a rule, either be the amendment of ITE Law,

\footnotetext{
${ }^{88}$ Marina Fyrigou - Koulori, "Blockchain Technology: An Interconnected Legal Framework For An Interconnected System", Journal of Law, Technology \& The Internet, Vol. 9, 2018. p.11-p.12

${ }^{89}$ Article 39 paragraph (1) POJK 13/2018

${ }^{90}$ The results of the interview with Prof. Dr. Sulistiowati, S.H., M. Hum as Professor of Commercial Law at the Faculty of Law, Gadjah Mada University (FH UGM), at the UGM Faculty of Law, March 23, 2019

${ }^{91}$ Article 374 of the Criminal Code (KUHP) "" The embezzlement committed by people whose control of goods is caused by a work relationship or because of a search or because they get paid for it, is punishable by a maximum of five years imprisonment."

${ }_{92}$ Teguh Prasetyo, “Hukum Pidana Edisi Revisi”, (Depok: RajaGrafindo Persada, Cet.9, Sept 2018), p..30.

93 Article 32 paragraph (1) of the ITE Law "Everyone intentionally and without rights or against the law in any way changes, adds, reduces, transmits, damages, removes, transfers, hides an Electronic Information and / or Electronic Documents belonging to someone else or public property. "

${ }^{94}$ Article 32 paragraph (2) of the ITE Law "Everyone intentionally and without rights or against the law in any way transfer or transfer Electronic Information and / or Electronic Documents to the Electronic System of someone who is not entitled.

${ }^{95}$ Article 32 paragraph (3) of the ITE Law "concerning acts as referred to in paragraph (1) which results in the opening of confidential Electronic Information and / or Electronic Documents being accessible to the public with data integrity that is not as appropriate."
} 
renewal of IKD related OJK rules, Bank Indonesia Regulation related changes digital finance, or just to create specific rules on the utilization of information technology and block-chain by the authorities. As for the content of the regulation obliged to accommodate the legality of block-chain technology service provider companies, consumer protection, the seizure of assets, the procedures for settlement of disputes in the event of a dispute, the dispute civil affairs and penal disputes.

\section{SUGGESTION}

A specified and technical regulation related to block-chain technology in Indonesia is needed in order to prevent crime and to uphold the principle of legality. Further Education for law enforcement agencies, officers in the PPATK, officers at the Bank Indonesia, officials at the financial services authority, the police, public prosecutors, judges linked to the block-chain system related way of uncovering the truth of material in case of a criminal offence using the block-chain system. Education and technical guidance was given by people who are experts in system block-chain; socialization is necessary for trade, financial services business actors to raise awareness of the on the risk of money laundering crime. Coordination and Joint Regulation is needed between Related Ministries, Police and related prevention and prosecution in case of a block-chain related criminal offenses.

\section{ACKNOWLEDGMENT}

The author would like to thank all those who have helped this research: Dr. (Hon). Jonathan L. Parapak, M.Eng.Sc as the Rector of Universitas Pelita Harapan; Prof. Dr. Bintan R. Saragih, S.H. always the Dean of the Faculty of Law, Universitas Pelita Harapan; Dr. Velliana Tanaya, S.H., M.H., as Director of the Faculty of Law, Universitas Pelita Harapan; Dr. Vincensia Esti P.S., S.H., M.Hum. as Chair of the Faculty of Law Study Program, Universitas Pelita Harapan; Yossi Niken R, S.H., M.H. as Deputy Chairperson of the University Pelita Harapan Law Faculty Study Program; Dr.-Ing. Ihan Martoyo, M.T., M.Sc, MTS as Chairperson of Universitas Pelita Harapan Research and Service Institute (Lembaga Penelitian dan Pengabdian Kepada Masyarakat Universitas Pelita Harapan); The Interviewees: Mrs. Pinuji Prasetyaningtyas, S.S,M.Si as a Digital Forensic Kasubdit, Directorate of Information Control, Digital Forensics, Investigation of the State Cyber and Code Agency (BSSN/ Pengendalian Informasi, Investigasi dan Forensik Digital Badan Siber dan Sandi Negara) located in Jl. Harsono RM 70, Ragunan, Jakarta Selatan; The Interviewees: Prof. Dr. Sulistiowati, S.H., M. Hum as Professor of Commercial Law in the Faculty of Law in University of Gadjah Mada (UGM FH) located on Jl. Sosio Yustisia No. 1; The Interviewees: Mrs. Suci, official at the Department of Law of Bank Indonesia, located in Jl. M.H. Thamrin No.2, Jakarta.; The Interviewees: Mr. Anton Dewantoro, as businessmen of Blockchain in Indonesia, doing Business Development for the address of Sandton Consulting, located in branch office in Ruko Bukit Cimanggu, Bogor; All parties that have assisted and supported this research with UPH LPPM Contract Numbers: 441 / LPPM - UPH / XII / 2018

\section{Books}

\section{REFERENCES}

Marzuki, P.M.. 2015. Penelitian Hukum, Kencana, Bandung: Kencana.

Muhammad, Abdulkadir.2004. Hukum dan Penelitian Hukum, Bandung: PT Citra Aditya Bakti.

S, Azwar. 2004. Metode Penelitian, Yogyakarta: Pustaka Pelajar.

Molcong. 2006. Metodologi Penelitian Kualitatif, Rosda Karya, Bandung: Rosda Karya.

Prasetyo, Teguh. 2015. Keadilan Bermartabat Perspektif Teori Hukum. Bandung: Nusa Media.

Prasetyo, Teguh. 2017. Pembaharuan Hukum: Perspektif Teori Keadilan Bermartabat Malang: Setara Press. 
Karo Karo, Rizky. 2019. Penegakan Hukum Kejahatan Dunia Maya (Cybercrime) Melalui Hukum Pidana. Karawaci: Penerbiit Fakultas Hukum UPH.

Siahaan, N.H.T. 2005. Pencucian Uang Dan Kejahatan Perbankan. Jakarta: Pustaka Sinar Harapan Sutedi. Adrian. 2008. Tindak Pidana Pencucian Uang. Bandung:PT Citra Aditya Bakti, Bandung. Husein, Yunus. 2007. Bunga Rampai Anti Pencucian Uang. Bandung : Terrace \& Library.

Prasetyo,, Teguh. 2018. Hukum Pidana Edisi Revisi. Depok: RajaGrafindo Persada.

\section{Journal, Scientific}

Redaksi "Blockchain, Sebuah Keniscayaan?" Jurnal Probank, 1 No.127 Tahun XXXIV MaretApril 2017

Fyrigou, Marina - Koulori, "Blockchain Technology: An Interconnected Legal Framework For An Interconnected System”, Journal of Law, Technology \& The Internet, Vol. 9, 2018. p.11-p.12

Karo Karo,Rizky, Artikel "Kejahatan Siber Perbankan", Kolom Opini Harian Kompas tanggal 27 Juli 2018.

Karo, R. K., \& Sebastian, A. "Juridical Analysis on the Criminal Act of Online Shop Fraud in Indonesia". Lentera Hukum, 6(1), 2019. 1-14.

N I, Fauzan, , Ahmad, "Teknologi Blockchain dan Peranannya dalam Era Digital", Jurnal BJB University, Vol 4, Des 2018, p.1.

Prasetyo,Teguh, "Kejahatan Pertambangan Dalam Perspektif Keadilan Bermartabat", Jurnal Perspektif Vol XXI No. 1 Tahun 2016 Edisi Januari , Nomor ISSN Cetak 1410- 3648 dan ISSN Online 2406-7385.

Prasetyo, Teguh, "Pancasila The Ultimate of All the Sources of Laws (A Diginifed Justice Perspective)", Journal of Law, Policy and Globalization, Vol.54, 2016. p.107.

Werbach, Kevin, "Trust, But Verify: Why the Blockchain Needs the Law", Berkeley Technology Law Journal, Vol. 33: 487, 2018, p.158. 